$$
\begin{aligned}
& \text { cumhuriget ilahigat dergisi 20, sy. 1 (Haziran 2016): 61-88 } \\
& \text { cumhuriget theology journal 20, no. 1 (June 2016): 61-88 } \\
& \text { \& Hakemli Araşterma Makalesi / Peer-reviewed Research Article \&8 }
\end{aligned}
$$

\title{
Usûlî Kıyasın Bilgi ve Amel Değeri
}

The Value of Method of Analogical Reasoning (qiyās)

Concerning Knowledge and Deeds

Temel Kacir*

ÖZ

“Ortak bir illete sahip olmaları nedeniyle, aslın hükmünün fer'e verilmesidir" şeklinde tanımlanan usûlî k1yasın bilgi ve amel değeri, ilk dönemden itibaren tartı̧̧ma konusu olmuştur. Şöyle ki; hüküm verme yetkisi sadece Şar'î́e ait olduğu halde usûlî kıyasın dinde hüküm verme anlamina geldiği ve bilgi değerinin de nasslarca yerilmiş zan olduğu gibi bazı argümanlar ileri sürerek usûlî kıyası reddedenler olsa da, çoğunluk tarafından usûlî kıyas aslî ve şer'î delil olarak kabul edilmiş ve elde edilen bu hüküm ile amel edilmesi gerekli

\begin{abstract}
The value of knowledge and deeds of the methodology of the reasoning defined such as "due to they have a common effective cause ('illa), the provision of principle (așl) is given to the branch (far ')" has been the subject of debate from the first period. That is, on the one hand there are some who reject the method of analogical reasoning by saying that although the authority of legislation belongs to Shāri'only, this method is to make legislation in the religion and that its value in knowledge is condemned as conjecture by the injunction (nașs). They also put forward some arguments as well. However, on the other hand the majority accepts the method of reasoning as an essential and shar'i (religious) argument. This study will not compare the opinions of
\end{abstract}

\footnotetext{
Yrd. Doç. Dr., Celal Bayar Üniversitesi, İlahiyat Fakültesi, Arap Dili ve Belâgatı Anabilim Dalı. Assistant Professor, University of Celal Bayar, Faculty of Theology, Department of Arab Language and Rhetoric Manisa/Turkey (temel_kacir@hotmail.com).

- cumhuriget ilahigat dergisi'nde yayımlanan makaleler, en az iki hakem tarafından çift taraflı kör hakemlik değerlendirmesine tabi tutulur. Ayrıca intihal içermediği özel bir yazılım kullanilarak kontrol edilir.

- cumhuriget ilahigat dergisi uses doubleblind review fulfilled by at least two reviewers. In addition, all articles are checked by means of a program in order to confirm they are not published before and avoid plagiarism.
}

DOI: http://dx.doi.org/10.18505/cuifd.12569

Geliş T. / Received Date: 05/04/2016

Kabul T. / Accepted Date: 13/05/2016 Yayın T./ Published Date: 15 Haziran /June 2016 
görülmüştür. Bu çalışma, usûlî k1yası kabul eden ve etmeyenlerin görüşlerini mukayese etmenin ötesinde, usûlî kıyasın salt aklî bir çaba olmadığını, kendisi ile ulaşılan bilginin naslarda yerilen zan olmayı aksine delile dayalı zannın en üst derecesi olduğunu ve bunun da furû f1kıhta amel için yeterli olduğunu naklî ve aklî deliller ile ele alan bir çalışmadır. Kıyasla ilgili genel bir çerçeve çizildikten sonra, usûlî kıyas ve deliller hiyerarşisindeki yeri ve kıyasın bilgi ve amelî değeri ile sınırlandırılan bu makale ile usûlî kıyasın bilgi ve amel değeri konusundaki tartışmalara açıklık getirilmek istenmektedir.

ANAHTAR KELİMELER: Kiyas, Delil, Bilgi, Zan, Amel. those who reject qiyās and that of those who approve it. By means of religious and rational evidences this study will deal with that the method of analogical reasoning is not a rational effort simply, that the knowledge gained by it is not a conjecture criticised by the injunctions, that it is the highest ranking conjecture based on the proof, and that it is sufficient to practice in the field of law. After a general frame is drawn about qiyās, this article has been limited with the place of qiyās in the hierarchy of evidence and its value concerning knowledge and practice. This article wants to clarify the discussions related to the value of knowledge and deeds of the methodology of the reasoning.

KEYWORDS: Analogical Reasoning, Evidence, Information, Conjecture, Deed.

\section{SUMMARY}

The value of knowledge and deeds of the methodology of the reasoning defined such as "due to they have common effective cause, the provision of principle is given to the branch" has been the subject of debate from the first period. In spite of some Mu'tazila and Zāhiriya who reject the reasoning by claiming that it expresses conjecture and a deed cannot be based on conjecture, the majority of jurists (fuqahā) use the method of reasoning and see it within the hierarchy of evidence. This indicates the value of the analogical reasoning for the fuqahā.

Location of the method of reasoning in the hierarchy of evidence changes according to the meaning ascribed to the concept of "evidence". But this change does not devalue the reasoning in terms of knowledge and practice because scholars ('ulama') by using the concept of evidence with a

$$
\text { cumhuriget ilahigat dergisi 20, sy. 1 (Haziran 2016): 61-88. }
$$


broad meaning covering conjectural knowledge have regarded the reasoning as independent evidence and have said that it is an individual principal proof separated from the first three principal proofs. On the other hand, some scholars by using the concept of evidence with narrow sense covering certain knowledge only have regarded the reasoning as independent evidence while others have counted it among the methods of inference (istinbāt). But both groups have approved that the reasoning expresses conjecture because the foremost factor in the reasoning is the assumption of mujtahid. Therefore, it is unavoidable that the knowledge gained by the reasoning expresses conjecture. But this conjecture is not a haphazard one. The most obvious indicator of this is that the reasoning is not independent evidence from the injunction (nașs). The one, who applies analogical reasoning, does neither invent a rule, nor does he give a new judgment. He just applies the provision of principle to the branch since he sees the similarity legitimating the reasoning. The reasoning is not alternative evidence to the injunction (nașs ) because the reasoning (qiyās) is not accepted where the injunction is present. The conditions as well asserted on the conformity between the feature determined as an effective cause (illa) and the general framework of the religion prove that qiyās is not a random reasoning.

Scholars, who have regarded the value of knowledge of the judgements gained by the methods of inference (istinbāt always seen the conjecture at the same level and have approved that conjectural meaning comes close to certain meaning as soon as indications increase. In this regard, they have developed even some criteria. For example, Bāqillānī has divided the value of knowledge of the judgement gained by inference (istinbāt ) depending on whether inference has based on a specific principle or not. He, also, has indicated that the value of knowledge of inference not based on a specific principle is conjecture (zann) and that the value of knowledge of inference based on a specific principle is "zann al-ghālib" (conjecture close to certainty). Bāqillānī has stated the analogical reasoning as an example of this. In this context, jurists have considered the value of knowledge of the reasoning to be the highest degree of "zann" by using some terms such as of $r a^{\prime} y$ al-ghālib, zann al-akbar, and zann al-ghālib. Even in Islamic law, this zann, in some cases, has been included in the conception of certainty (yaqin). For example Ali Haydar, the commentator of Majalla, has described yaqin such as that it is to know the existence or non- 
existence of something with certainty or with zann al-ghālib. Eventually, while the probable knowledge has not been accepted as a proof in principle in Kalām theology, "ilm al-ghālib al-z̧ann" has been accepted as a method of ijtihād in the methodology of Islamic jurisprudence. It is especially emphasized that to act by the conjectural knowledge is necessary. Then, if mujtahids were content with certain knowledge only in judicial matters, ijtihād would not be mentioned and connection of the jurisprudence with life would have been broken.

Scholars have brought evidences from the Qur'ān and Sunnah of the Prophet about necessity of acting by conjectural knowledge. Scholars, alongside with the verses of the Qur'ān (al-Baqarah/230; al-Mumtahinah/60; and Yūsuf/81) have provided the case in which the Prophet adjudges through conjectural knowledge between two claimants. The Prophet said that let no one perform prayer until arriving in Banī Kurayza, and Companions of the Prophet deduced from the Prophet's statement two different results. According to scholars, this is also evidence because the Prophet approved those who deduce different results through adjudging basing on conjectural knowledge. Thus we can say that when a mujtahid deduces different results from the same qiyās, it does not make an act based on these results problematic. Moreover, the consensus of Companions has been given as evidence in the matter of acting by conjectural knowledge.

Scholars have brought many rational evidences regarding acting by conjectural knowledge. In this direction, they have compared qiyās to khabar al-wähid. According to them, if khabar al-wähid whose the value of knowledge is not certain, is sufficient for a judicial rule, the conjectural knowledge gained by qiyās is likewise sufficient for it. Scholar again have compared qiyās to that the explained word (lafz muavval), though has the properties of mistake and probability, requires to act and that the general word (laf? 'umüm) which assigned for once is accepted as sufficient for act. Moreover, a kind of the method of "tahqiq al-manāt" accepted unanimously shows that the conjectural knowledge is evidence.

Finally, on the basis of the comments of "muhattie and musavvibe", it can be demonstrated that to act with the conjectural knowledge gained

$$
\text { cumhuriget ilahigat dergisi 20, sy. 1 (Haziran 2016): 61-88. }
$$


by qiyās is necessary because according to both comments, even though there are not Shāri's explicit address about the rule gained by qiyās, it is accepted that there are his address by the way of signification. A mujtahid is responsible to reach this rule. Due to mujtahid reaches this result by making an effort to understand the divine will, it has the religious (shar $\bar{\imath}$ ) quality as a result. For this reason, qiyās has been accepted as the fourth proof, and acting through this gained rule has been considered necessary.

\section{GİRIŞ}

Genel olarak, İslam hukuk tarihçileri tarafından Hz. Peygamber döneminden başlamak üzere, sahabe ve tabiîn döneminde geniş anlamıyla kullanıldığı ifade edilen re'y kelimesinin, ${ }^{1}$ İmam Şafiî (ö. 204/820) tarafından kıyas olarak sistematize edildiği kabul edilmektedir. ${ }^{2}$ Bununla birlikte, İmam Şafî̀' den hemen sonra kıyasın bilgi ve amel değeri tartışılmaya başlanmıştır.

İllet birliğinden yola çıkarak nasların hüküm alanının genişletilmesi anlamına gelen usulî/şerî kıyasa ${ }^{3}$ ilk itirazın İbrahim en-Nazzam (ö.

$1 \quad \operatorname{Re}^{\prime}$ yin tarihi gelişimi ve kullanımları için bk., İdris Cuma, er-Re'y ve Eserühü fi'l-Fıkhi'lİslâmî (Kahire: Matbaatü İsa el-Babî el-Halebî, 2006), 38-391; Adnan Koşum, İslam Hukuk Tarihinde Kıyasın Oluşum ve Geliş̧im Süreci (Başlangıcından Mezheplerin Teşekkülüne Kadar) (İzmir: Işık Akademi Yayınları, 2010), 19-47.

2 Muhammed Ebû Zehra, İmam Şafî̀, trc. Osman Kesikoğlu (Ankara: Diyanet İşleri Başkanlığı, 1969), 272-273; Ahmet Hasan, İslam Hukukunun Doğuşu ve Gelişimi, trc. Ali Hakan Çavuşoğlu-Hüseyin Esen (İstanbul: İz Yayıncılık, 1999), 213; Schacht Joseph, İslam Hukukuna Giriş, trc. Mehmet DAĞ-Abdülkadir ŞENER (Ankara: Ankara Üniversitesi Basım Evi, 1997), 56; Koşum, İslam Hukuk Tarihinde Kıyasın Oluşum ve Gelişim Süreci, 31, 35, 90; H. Yunus Apaydın, “Kıyas”, Türkiye Diyanet Vakfi İslam Ansiklopedisi, c. 25, (Ankara: TDV Yayınları,2002), 530-531. Farklı yaklaşım için bk. Soner Duman, “Şafiî'nin Hukuk Metodolojisinde Kıyas Kavramının Anlam ve Kapsamı", Ekev Akademi Dergisi 14 sy. 42 (Kış 2010): 149-162.

3 İslâmî ilimlerde kullanılan "kıyas" sözcüğü, genellikle ya "usûlî/şer'î/fıkhî kıyas" anlamında ya da "mantıkî kıyas" anlamında kullanılır. Mantıkta, "Öncül (mukaddime) adı verilen birden fazla önerme ile sonuç adı verilen bir önerme arasında mantıkça geçerli olan bir ilişki kurmak" anlamında kullanılan kıyas kavramı, tümdengelim (dedüksiyon, talil), tümevarım (endüksiyon, istikra) ve benzetme (analoji, temsil) türlerinden oluşmaktadır. Usûlî kıyas mantıktaki analojiye/temsile tekabül eder. bk. Muhammed b. A'la Tehânevî, Keşşâfı Istılahâti'l-Fünûn ve'l-Ulûm, thk. Ali Dahruc (Beyrut: Mektebetü Lübnan, 1996), 3: 525, 530. Mantıkî kıyasla usûlî kıyas arasındaki farklar için bk. Hüseyin

$$
\text { cumhuriget theology journal 2o, no. ( (June 2016): 61-88. }
$$


231/849) tarafından yapıldığı, daha sonra metotları farklı olsa da ${ }^{4}$ bir kısım Şiî ve Zahirîlerin kıyasa karşı çıktıkları ${ }^{5}$ ve bu düşünceyi Davud b. Ali'nin (ö. 270/884) devam ettirdiği ifade edilmektedir. ${ }^{6}$ Buna karş1lık fukahanın büyük çoğunluğu tarafından kıyas ameli hükümlerde hüccet olarak kabul edilmiştir.7

Kıyası hüccet olarak kabul edenler arasında da kıyasın içeriğine yönelik farklı yaklaşımlar mevcuttur. Şöyle ki; Iraklıların kullandığı kıyasın daha sistematik olduğu, Şafiî̀'de olduğu kadar şeklî ve katı olmadığı, Medinelilerin kıyasının genellikle ittifak edilen uygulamaya vurgu yaptığı, Iraklıların kullandığı kıyasın ise daha çok mantıkî tutarlılık arayışı içerisinde olduğu ifade edilmiştir. ${ }^{8}$

Bu farklı yaklaşımlara rağmen özellikle H. III. asırda ve sonrasında illet merkezli geliştirilen kıyas, fukaha tarafından kullanılmış, fakat ilk dönemlerde re'y kavramının genişliği, kıyas kavramının birden fazla anlamda kullanılmış olması ve kıyasın tanımı üzerinde ittifak sağlanamaması nedeniyle kıyasın bilgi ve amel değeri tartışılmaya devam etmiştir.

Çaldak, Kıyas'ın Mantıkta ve İslami ilimlerde Kullanım Biçimi, Cumhuriyet Üniversitesi İlahiyat Fakültesi Dergisi, 11, sy. 1, (2007): 235-262; Soner Duman, er-Redd Ale'1-Mant1kıyyîn Adlı Eseri Çerçevesinde İbn Teymiyye'nin Fıkhî Kıyas ile Mantıkî Kıyas Arasındaki İliş̧kiye Dair Görüşleri, Hikmet Yurdu, 3, sy. 6 (Temmuz-Aralık 2010): 193-210.

4 Usûlcüler kıyasın dünyaya ait maslahatlar konusunda delil olduğunda ittifak ettikleri halde dinî konularda delil olması ile ilgili farklı görüşler ileri sürmüşlerdir. 1-Cumhura göre kıyas, aklen caiz, şer'an vaciptir. 2-Şafiîlerden Kaffal eş-Şâşî (ö. 365/976) ve Mutezilîlerden Ebu'l-Hüseyn el-Basrî'ye göre kıyasla amel hem şer'an hem aklen vaciptir. 3Kaşanî, Nehrivanî ve Davud bin Ali'ye göre ise; a-Aslın illetinin sarih veya îma yoluyla beyan edilmiş olması. b-Fer' deki hükmün asıldan daha evla olması durumlarında kıyasla amel etmek şer' an vaciptir. Aksi takdirde haramdır. 4-İbn Hazm ve ona tabi olanlara göre kıyasla amel etmek caiz değildir. 5-Şiâ'nın İmamiyye grubu ile Nazzamdan bir görüşe göre ise kıyasla amel etmek aklen muhaldir. Bk. Muhammed Ebu'n-Nur Züheyr, Usûlü'lFikh (Kahire: el-Mektebetü'l-Ezheriyyetü li't-Türas, 2004), 4: 5.

5 el-Hüseyn Halife Ba Bekr, el-İctihad bi'r-Re'y fi Medreseti'l-Hicazi'l-Fikhiyye (Kahire: Mektebetü'z-Zehra, 1998), 38.

6 Ebu Abdullah Muhammed Şevkanî, İrşadü'l-Fuhul ila Tahkiki'l-Hak min İlmi'l-Usûl, thk. Ebu Hafs Sami b. el-Arabî (Riyad: Daru'l-Fazile, 2000), 2: 846-847; Abdülaziz Buhârî, Keş̧ü'l-Esrar ala Usûli'l-Pezdevî (Beyrut: Daru'1-Kütübi'l-İlmiyye, 1994), 3: 400.

$7 \quad$ Fahreddin Razî, el-Mahsûl fi İlmi'l-Usûl, thk. Taha Cabir Feyyaz el-Alvanî (Beyrut: Müessesetü'r-Risale, 1997), 5: 26.

8 Hasan, İslam Hukukunun Doğuşu, 161-162.

$$
\text { cumhuriget ilahigat dergisi 20, sy. 1 (Haziran 2016): 61-88. }
$$


Bu genel çerçeveyi çizdikten sonra şimdi usûlî kıyas ve deliller hiyerarşisindeki yeri, bilgi değeri ve bu bilgi ile amel etme konusundaki yaklaşımlara geçebiliriz.

\section{USÛLÎ KIYAS VE DELİLLER HIYYERARȘISİNDEKİ YERİ}

Akıl yürütme metotlarından biri olarak kabul edilen kıyas, sözlükte, "ölçmek, karşılaştırmak ve iki şey arasındaki benzerlikleri tespit etmek" anlamına gelen "k.y.s" kökünden bir mastardır. ${ }^{9}$

Fıkıhta, "şer'î kıyas, fıkhî kıyas, usûlî kıyas" biçiminde kullanılan kıyas, "Ortak bir illete sahip olmaları nedeniyle, aslın hükmünün fer'e verilmesidir"10 şeklinde tanımlanmıştır.

Delil ise sözlükte, "Yol göstermek, irşat etmek"11 manasına gelir. Istılahta ise biri geniş, diğeri dar anlamı olmak üzere iki tanımı vardır. Geniş anlamıyla; "Üzerinde doğru düşünmek suretiyle haberî bir sonuca ulaştıran şey", ${ }^{12}$ dar anlamı ise; "Medlulü hakkında kesin bilgiye ulaştıran şeydir."13 Geniş anlamını esas alan usulcüler, zannî bilgiye ulaştıran emareyi de delil olarak kabul etmiş ve delili kat'î-zannî olarak kısımlara ayırmışlardır. ${ }^{14}$ Dar anlamını esas alan usûlcüler ise, medlulü hakkında kesin bilgiye ulaştıran şeylere delil, zannî bilgiye ulaştıranlara ise emare ismini vermişlerdir. ${ }^{15}$

İbn Manzur, Lisanü'l-Arab (Beyrut: 2000), 12: 234.

Muhammed Ebû Zehra, Usûlü'l-Fıkh (Kahire: Daru'l-Fikri'l-Arabî, ts.), 218.

İbrahim Mustafa, el-Mu'cemu'l-Vasîd (Kahire: el-Mektebetü'l-İslamiyye, 1992), 294.

12 Bedrüddin Muhammed Zerkeşî, el-Bahrü'l-Muhît fi Usûli'l-Fıkh (Ğardek: Daru's-Safve, 1992), 1: 35; Seyfeddin Âmidî, el-İhkâm fî Usûli'l-Ahkâm (Riyad: Daru's-Samı̂̂̂, 2003), 1: 23.

13 Zerkeşî, el-Bahrü'l-Muhît, 1: 35; Âmidî, el-İhkâm, 1: 23; Ebû İshak Şirâzî, Şerhu'l-Lüma', thk. Abdülmecid Türkî (Beyrut: Dârü'l-Garbi'l-İslâmî, 1988), 1: 155-156.

14 Âmidî, el-İhkâm, 1: 23; Ebû'l-Muzaffer Semânî, Kavâdıu'l-Edille fi'l-Usûl, thk. Muhammed Hasan (Beyrut: Daru'1-Kütübi'l-İlmiyye, 1997), 1: 43.

15 Zerkeşî, el-Bahrü'l-Muhît, 1: 35; Razî, Mahsûl, 1: 88; Âmidî, el-İhkâm, 1: 23. cumhuriget theology journal 2o, no. (June 2016): 61-88. 
Delilleri farklı açılardan kısımlara ayıran ${ }^{16}$ usûlcülerin çoğu, Kitap, sünnet, icma ve kıyası şer'î delil olarak kabul ederken, ${ }^{17}$ bazıları ise Kitap, sünnet ve icma'ı şer'î delil olarak kabul etmiş, kıyası ise farklı bir konumda ele almışlardır. ${ }^{18}$ Örneğin Pezdevî (ö. 482/1089) ve onu takip eden usulcüler; şeriatın asılları üçtür diyerek Kitap, sünnet ve icma'ı zikrettikten sonra dördüncü asıl olarak kıyası ayrı zikretmişlerdir. ${ }^{19}$ Kıyasın diğer delillerden ayrı bir dördüncü asıl olarak zikredilmesi, ilk üç delilin kat'î, kıyasın ise zannî kabul edilmesiyle ${ }^{20}$ ya da kıyasın delilden ziyade diğer üç delilden hüküm istinbat etme metodu olarak kabul edilmesiyle izah edilmiştir. $^{21}$

Delilleri bilgi değeri açısından kat'î ve zannî olarak kısımlara ayıran usûlcüler bu konuda farklı tasnifler de yapmışlardır. Örneğin fukaha metoduna göre yazılan bazı eserlerde, deliller mûcibe ve mücevvize olarak ikiye ayrılmış; Kitap, Hz. Peygamber'den işitilen haber, mütevatir haber ve icma "mûcibe delil" olarak, tahsise uğramış âmm, müevvel ayet, haberi vahid ve kıyas ise "mücevvize delil" olarak kabul edilmiştir. ${ }^{22}$ Mütekellimîn metoduna dair yazılan bazı eserlerde ise deliller; asl, ma'kûlü'l-asl ve istishâbü hal şeklinde üç kısımda ele alınmıştır. Bu tasnifde "asl" ile Kitap, sünnet ve icma; "ma'kûlü'l-asl" ile lahnü'l-hitâb, fehve'l-hitâb, ma'ne'l-hitâb (kıyas), istidlal bi'l-hasr gibi naslardan hüküm çıkarmada

16 Delil içerdiği bilginin kaynağı açısından aklî-naklî, ulaştırdığı sonuç bakımından kat ìzannî, üzerinde ittifak edilip edilmeme açısından müttefekün aleyh-muhtelefün fih olarak kisımlara ayrilır.

17 Abdülalî Leknevî, Fevatihü'r-Rahamût bi-Şerhi Müsellemi's-Sübût, tsh. Abdullah Mahmûd Muhammed Ömer (Beyrut: Dârü'l-Kütübi'l-İlmiyye, 2002), 2: 3; Sem'ânî, Kavâdı', 1: 14, 31.

18 Zerkeşî, el-Bahrü'l-Muhît, 1: 17; Ebu Bekr Serahsî, Usûlü's-Serahsî, thk. Ebu'l-Vefa elEfğanî (Beyrut: Daru'1-Kütübi'1-İlmiyye, 1993), 1: 279; Buhârî, Keşfǘl-Esrar, 1: 33-34.

19 Pezdevî, Usûli'l-Pezdevî, Keşfǘl-Esrar ile birlikte, (Beyrut: Daru'l-Kütübi'l-İlmiyye, 1994), I, 33; Buhârî, Keş̧ü'l-Esrar, 1: 33-35; Ebu'l-Berekat Nesefî, Keşfu'l-Esrar, Nuru'l-Envar ve Kamerü'l-Akmar'la birlikte, (İstanbul: İhsan Kitabevi, 1986), 1: 2-9.

20 Pezdevî, 1: 33; Buhârî, Keşfü'l-Esrar, 1: 33-35; Nesefî, Keş̧fu'l-Esrar, 1: 2-9.

21 Ali Bardakoğlu, "Delil”, Türkiye Diyanet Vakfi İslam Ansiklopedisi, c. 9, (Ankara: TDV Yayınları,1994), 140.

22 Ebû Zeyd Debûsî, Takvîmu'l-Edille fi Usûli'l-Fikh, thk. Halil Muhyiddin el-Meys (Beyrut: Daru'l-Kütübi'l-İlmiyye, 2001), 18, 19, 168; Serahsî, Usûl, 1: 279.

$$
\text { cumhuriget ilahigat dergisi 20, sy. 1 (Haziran 2016): 61-88. }
$$


kullanılan dil ve mantık kuralları ile akıl yürütme kuralları kast edilmiştir. ${ }^{23} \mathrm{Bu}$ taksimde kıyas, hitâbın anlamı kapsamında zikredilmiş ve bu yönüyle lafzi delalet şekilleri olan nass ve zâhirin mukabili olarak kabul edilmiştir. ${ }^{24}$ Kıyası daha dar anlamda alanlar ise, kıyas dışındaki diğer aklî delil ve metotları istidlal başlığı altında toplamış, kıyas ve istidlali bu üç delile ilave ederek şer'î delilleri beş olarak zikretmiştir. ${ }^{25}$ Yapılan bu tasniflerde kıyasın "mücevvize delil" olarak kabul edilmesi ya da "ma'kûlü'lasl" kapsamında zikredilmesi, kıyasın deliller arasındaki yerinin ve hüküm çıkarmadaki rolünün farklılığına işarettir.

Yine bu tasniflerden anlaşılacağı üzere, kıyasın müstakil delil olupolmama konusu tartışmalıdır. ${ }^{26}$ Âmidî (ö.631/1233), İbn Hacib (ö. 646/1249), Kemal b. Hümam (ö. 861/1457) ve İbn Abdüşşekûr (ö. 1119/1707) gibi âlimler kıyası, Kitap ve sünnet gibi müstakil bir delil olarak kabul etmiş, usûlcülerin çoğu ise, şer'î bir delil olarak kabul ettikleri kıyası, müstakil bir delil olarak kabul etmemiştir. ${ }^{27}$ Cüveynî (ö.478/1085), Gazzâlî (ö.505/1111) ve Kiyâ el-Herrâsî (ö. 504/1110) gibi usûlcüler, kıyasın fıkhın delillerinden olmadığını savunmuş, bu nedenle olsa gerek Gazzâlî kıyasa, deliller arasında değil, delillerin anlaşılmasına yönelik istinbat metotları arasında yer vermiştir. ${ }^{28}$

Kıyasın deliller hiyerarşisindeki konumu ile ilgili bu farklı yaklaşımlar kıyasın tanımına yansımıştır. Şöyle ki; kıyası şer'î bir delil olarak

23 Ebü'l-Velid Bacî, İhkamu'l-Fusûl fi Ahkâmi'l-Usûl, thk. Abdü'l-Mecid Türkî, (Beyrut: Dârü'l-Ğarbı'1-İslâmî, 1995), 193, Sem'ânî, Kavâdı', 1: 31; Bardakoğlu, “Delil”, 140.

24 Apaydın, "Kıyas", 534.

25 Âmidî, el-İhkâm, 1: 211-212; Bardakoğlu, "Delil”, 140.

26 Ebû Nasr Taceddin Sübkî, Ref'u'l-Hacib an Muhtasar'i-bni'l-Hacib, thk. Ali Muhammed Muavviz, Adil Ahmed Abdülmevcud (Beyrut: Âlemü'l-Kütüb, 1999), 1: 164.

27 Abdülkerim Nemle, el-Mühezzeb fì İlmi Usûli'l-Fikhi'l-Mukaren: Tahrir li-Mesailihi ve Dirasetiha Dirase Nazariyye Tatbikiyye (Riyad: Mektebetü'r-Rüşd, 1999), 4: 1825-1829; Mustafa Şelebî, Usûlü'l-Fikhi'l-İslamî (Beyrut: ed-Darü'l-Cami'iyye, ts.), 202.

28 Bk. Zerkeşî, el-Bahrü'l-Muhît, 5: 27-28; İsa Mennun, Nibrasü'l-Ukûl fî̀ Tahkiki'l-Kıyas İnde Ulemâi'l-Usûl (Kahire: Matbaatü'z-Tezamüni'l-Ehva, 1345), 1: 196-197. Kiyasın delil ya da metot kabul edilmesiyle ilgili halen devam eden tartışmalar ayrı bir çalışmayı hak etmektedir.

cumhuriget theology journal 20, no. 1 (June 2016): 61-88. 
kabul eden Âmidî, ${ }^{29}$ İbn Hacib, ${ }^{30}$ Kemal b. Hümam, ${ }^{31}$ İbn Abdüşşekûr ${ }^{32}$ gibi âlimler kıyası "Hükmün illetinde, fer'in asla eşitlenmesi"33 anlamına gelecek şekilde tanımlarken, müctehidin bir ameliyesi olarak kabul eden Kâdî Ebû Bekir el-Bâkillânîi ${ }^{34}$ (ö. 403/1013), Cüveynî, ${ }^{35}$ Gazzâlî,, Razî (ö. 606/1209),,37 Sadrüşşerîa (ö. 747/1346) ${ }^{38}$ gibi âlimler ise, "Ortak bir illete sahip olmaları nedeniyle aslın hükmünü fer'e aktarmaktır" şeklinde birbirine benzer tanımlar yapmışlardır.

Tanımlar karşılaştırıldığı zaman birinci gurupta yer alanlar kıyasın tarifinde "istiva ve musavat" gibi kavramları kullanarak kıyasın müstakil bir delil olduğuna, ikinci gurupta yer alanlar ise, tarifte "haml", "ispat", "ilhak", "ta'diye", "tesviye", "red" gibi kavramları kullanarak müçtehidin ameli olduğuna vurgu yapmışlardır. ${ }^{39} \mathrm{Bu}$ farklılı̆̆ dirmiştir. Tanımda "istiva" ve "müsavat" gibi kavramları kullananlar, hükümlerin nasların sadece literal anlamında olmadığı, müçtehidin herhangi bir çabası olmasa da "illet ya da vasıfta ortak olan, hükümde de ortaktır" kuralından hareket ederek, hükmü açıklanmayan fakat aynı benzerliği ta-

29 Âmidî, el-İhkâm, 3: 237.

30 İbn Hacib, Muhtasar'i-bni'l-Hacib, Ref'u'l-Hacib ile birlikte, thk. Ali Muhammed Muavviz, Adil Ahmed Abdülmevcud (Beyrut: Âlemü'l-Kütüb, 1999), 4: 137.

31 Kemalüddin İbn Hümam, Kitabü't-Tahrir, Teysir'u-Tahrir ile birlikte (Misır: Matbaatü Mustafa el-Babî el-Halebî, 1351), 3: 264.

32 İbn Abdüşşekür, Müsellemü's-Subût, Fevatihu'r-Rahamût ile birlikte, zbt. Abdullah Mahmud Muhammed Ömer (Beyrut: Daru'l-Kütübi'l-İlmiyye, 2002), 2: 297.

33 İbn Hacib, Muhtasar'i-bni'l-Hacib, 4: 137.

34 Ebû Bekr Muhammed Bâkıllânî, et-Takrib ve'l-İrşad: es-Sagir, thk. Abdülhamid b. Ali Ebû Zenid (Beyrut: Müessesetü'r-Risâle, 1998), I, 224; Âmidî, el-İhkâm, 3: 231.

35 İmamü'l-Harameyn Cüveynî, el-Burhan fì Usûli'l-Fıkh, thk. Abdülazim ed-Dib (Devha: Câmiatu Katar, 1978), 2: 745.

36 Ebû Hamid Gazzâlî, el-Mustasfâ min İlmi'l-Usûl, thk. Hamza b. Züheyr Hafız, (Beyrut: Müessetü'r-Risale, 1997), 3: 481.

37 Razî, Mahsûl, 5: 11.

38 Ubeydullāh b. Mes'ûd Sadrüşşerîa, et-Tavzîh Şerhü't-Telvih ile birlikte, (Beyrut: Dârü'lKütübi'l-İlmiyye, 1957), 2: 52.

39 İbn Abdüşşekür, 2: 297-298; Nemle, 4: 1827-1828. Genel anlamda ilk dönem Hanefî usûlcülerinden nakledilen efradını cami’ ağyarını mani’ bir tanım yapılmamış olsa da, Hanefîlerde genellikle kıyas tanımlarında "red" ve "tadiye" gibi kavramları kullanmışlardır. Bk. Cessâs, Ebû Bekr, el-Fusûl fi'l-Usül, thk. Acil Casim en-Neşmi, Kuveyt: Vüzaratü'1Evkafi ve'ş-Şuû'ni'l-İslamiyyeti, 1994, 4: 9, 90; Debûsî, Takvîmu'l-Edille, 260; Serahsî, Usûl, 2: 118, 144; Buhârî, Keşfü'l-Esrar, 3: 399.

$$
\text { cumhuriget ilahigat dergisi 20, sy. 1 (Haziran 2016): 61-88. }
$$


şıyan durumların da nassta zikredilen hüküm ile eşit olduğu görüşündedirler. Hâlbuki tanımda "haml", "ispat", "ilhak", "ta'diye", "tesviye", "red" gibi kavramları kullananlar ise, fer'de bulunan hükmün ancak müçtehidin çabası ile ortaya çıktığı, bu anlamda hükümdeki eşitliğin gerçek anlamda bir eşitlik olmadığı, müçtehidin nazarında bir eşitlik olduğu görüşündedirler. ${ }^{40}$

Tanımındaki bu farklılık, kıyasın delil ya da metot kabul edilmesi kanaatine bir dayanak teşkil etse de, bunun ötesinde usûlî bir sonuç doğurduğu kanaatinde değiliz. Zira fer'deki hükmün ister ibtidaen varlı̆̆ 1 kabul edilsin isterse müçtehidin çabası sonucunda asıldan fer'e intikal ettirildiği kabul edilsin bu durum kıyasın bilgi ve amel değeri açısından herhangi bir farklılık oluşturmamaktadır. Hatta şunu da belirtmeliyiz ki, bu yaklaşımın genel anlamda usûldeki hüküm teorisi açısından da pratik bir karşıllı̆ı bulunmamaktadır. ${ }^{41}$

\section{KIYASIN BİLGİ DEĞERİ}

Fıkıh usûlünde mükellefin fiilleriyle alâkalı Şârî'in hitâbı veya hitâbının eseri şeklinde tanımlanan hüküm; ya haber ya da istinbat yoluyla elde edilir. Hiç şüphesiz bunlardan her birinden elde edilen hükmün bilgi değeri farklıdır. ${ }^{42}$ İlk dönemden itibaren bu farklılığa dikkat çekilmiştir. Örneğin Şâfi'î (ö. 204/920) delillerden elde edilen bilginin değerini iki kısma ayırmış, sübût ve delaleti kat'î olan naslarla hüküm vermeyi "zahir ve batında hak ile hükmetmek", sübût ve delaleti zannî olan naslarla ve yine bu şekilde olan icma ve kıyasla hüküm vermeyi ise "zahirde hak ile hükmetmek şeklinde ifade etmiştir. ${ }^{43}$ Yine Cessâs (ö.370/980) ve Debûsî (ö.430/1039) gibi alimler, istidlal türlerine ilişkin yaptıkları ayırımda delil-

Şelebî, Usûlü'l-Fıkh, 202.

41 Konu kelâm-i nefsî ile ilgili olarak değerlendirilmiştir. Kelâm-i nefsî konusu ise aslında Kelâmî bir mesele olmasına rağmen usûl kitaplarında daha ziyade hükmün tanımındaki "hitâb" kaydının incelenmesinde ele alınmıştır. Bk. Teftazanî, Sa'deddin, Şerhü't-Telvih ale't-Tavzih (Beyrut: Dârü'l-Kütübi'l-İlmiyye, 1957), 1: 13-20, 2: 53.

42 Bâkıllânî, et-Takrib, 1: 221-223.

43 Muhammed İdris Şafiî, er-Risale, thk. Ahmed Muhammed Şakir, (ts: Darü'l-Kütübi'l-illmiyye, Beyrut), 478-479. cumhuriget theology journal 2o, no. 1 (June 2016): 61-88. 
leri kesin bilgi ve zann-1 galip ifade edenler olarak iki kısma ayırmış, birinci tür delillerin kesin bilgiye, ikinci tür delillerin ise rey-i galibe ve zann1 ekbere ulaştırdığını ifade etmişlerdir. ${ }^{44}$ Cessâs rey-i galibe ve zann-1 ekbere ulaştıranları içtihat kavramı altında toplamış ${ }^{45}$ ve usûlî/şer'î kıyası da bu başlık altında zikretmiştir. ${ }^{46}$

İstinbat yoluyla elde edilen hükümlerin bilgi değeri genellikle zan olarak kabul edildiği halde, bu zan her zaman aynı seviyede görülmemiştir. ${ }^{47}$ İbn Rüşd'ün (ö.595/1198) ifade ettiği gibi, naslardan istinbat yoluyla elde edilen hükümlerin bilgi değeri, nasların metnindeki ifade ve göstergelerine bağlıdır ve her zaman ayn seviyede değildir. Delaletin kuvvet derecesine bağlı olarak, düşük ve zayıf seviyede tespit edilen anlamların yanı sıra, zann-ı galiple tespit edilen anlamlar da vardır. Karineler arttıkça zannî anlamın kat'îliğe olan yakınlığ cesini tespit noktasında bazı kriterler dahi ileri sürülmüştür. Örneğin Bâkıllânî; istinbat yoluyla elde edilen hükmün bilgi değerini, istinbatın belirli bir asla dayanıp dayanmamasına göre açıklamıştır. Belirli bir asla dayanmayan istinbatların aklî emareler olduğunu ve bunların zan ifade ettiğini beyan eden Bâkıllânî, bu kısma ihramlı kişinin avlanmasında avladığının dengi olarak verilecek cezada hayvanın takdirini, itlaf edilen malların kıymetlerinin takdirini, cinayetlerdeki erş bedellerinin takdirini, şahitlerin adaletini vb. örnek olarak vermiştir. Belirli bir asla bakılarak yapılan istidlallerin bilgi değerinin ise zann-1 galib olduğunu belirten Bâkıllânî, buna örnek olarak da kıyası vermiştir. ${ }^{49}$

Görüldügü gibi, hakkında nas olmayan konularda şer'î hükme ulaşma yollarının en önemlilerinden biri olarak kabul edilen kıyasın bilgi değeri, zann-ı galip olarak kabul edilmiştir. Ancak bazı Şafiî usûlcüler, ka-

Cessâs, el-Fusûl, 4: 9-10; Debûsî, Takvîmu'l-Edille, 272.

45 Cessâs, el-Fusûl, 4: 11-12.

46 Cessâs, el-Fusûl, 4: 10-12.

47 Ebû Ya'la el-Ferra, el-Udde fî Usûli'l-Fıkh, thk. Ahmed b. Ali Seyr Mübarekî, (Riyad: 1990), I, 83; Zerkeşî, 1: 75-77.

48 İbn Rüşd, ez-Zarurîfî Usûli'l-Flķh ev Muhtasaru'l-Mustasfa, thk. Cemalüddin el-Ulvî (Beyrut: Daru'1-Ğarbi'1-İslamî, 1994), 126-128.

49 Bâkıllânî, et-Takrib, 1: 221-224. cumhuriget ilahiyat dergisi 20, sy. 1 (Haziran 2016): 61-88. 
tegorik ayırıma giderek kıyasın kat'î veya zannî olabileceğini ifade etmişlerdir. ${ }^{50}$ Buna göre; kıyası oluşturan iki öncül kat'î olduğunda kıyas kesinlik ifade eder. ${ }^{51} \mathrm{Bu}$ sonuca, illetin varlığı asılda kesin olduğu gibi fer'de de kesin olması ile ulaşılır. ${ }^{52} \mathrm{Bu}$ da iki şekilde gerçekleşir.

a- Hükmü bildirilmeyen (meskûtun anh) illet açısından hükmü bildirilen (mansusun aleyh)den daha evla olduğu durum..$^{53}$ Örneğin anne babaya öf deme ve onları azarlama" 54 ayetinde, ibarede zikredilen öf deme ve azarlama yasaklandığ 1 gibi, ibarede zikredilmeyen her türlü eziyet, dövme ve kötü söz söyleme de yasaklanmıştır. Burada hükmün meskûtun anh hakkındaki sübûtu, mansusun aleyh hakkındaki sübûtundan daha üstündür. Çünkü işaret edilen fiillerde anne-babaya eziyet verme özelliği, "öf" demekten daha fazla bulunmaktadır.

b- Hükmü bildirilmeyen (meskûtun anh) illet açısından hükmü bildirilene (mansusun aleyh) eşit olduğu durum. Örneğin "Haksız yere yetimlerin mallarını yiyenler, karınlarına sadece ateş doldurmaktadırlar ve çılgın bir ateşe gireceklerdir" 55 ayetinde, ibarede zikredilen haksız yere yetimlerin mallarının yenmesi yasaklandığı gibi, ibarede zikredilmeyen yakmak, dağıtmak, muhafazasında kusurlu davranmak vb. yollarla yetim malının yok olmasına sebebiyet vermek de yasaklanmıştır. Burada hüküm açısından meskûtun anh ile mansusun aleyh birbirine eşittir. Çünkü yetimin malını haksız yere yiyerek yetimin malına zarar verme özelliği, işaret edilen fiillerde de aynı şekilde bulunmaktadır. ${ }^{56}$

50 Cüveynî, 2: 787; Razî, Mahsûl, 5: 122; Cemalüddin İsnevî, Nihayetü's-Sû'l fí Şerhi Minhaci'lVuŝ̂l, Süllemü'l-Vusul ile birlikte, (Kahire: Âlemü'l-Kütüb, 1343), 4: 26-27; Âmidî, elİhkâm, 4: 5-6.

51 Razî, Mahsûl, 5: 122-123; Mennun, Nibras, 1: 180.

52 Mennun, Nibras, 1: 180.

53 İki kişinin şehadetinin geçerli olduğu yerde üç kişinin şahitlik etmesi, şaşı ya da topal olan hayvan kurban için yeterli olmadığına göre kör ya da iki ayağı kesik olan hayvanın evleviyetle kurban olamaması gibi. Muvaffikuddin İbn Kudâme, Ravzatü'n-Nâzır ve Cünnetü'l-Munâzir, Nüzhetü'l-Hatır ile birlikte (Riyad: Mektebetü'l-Meârif, 1984), 2: 254.

54 İsrâ $17 / 23$

55 Nisa $4 / 10$

56 Bu iki maddeyi kıyasın kat'î kısmı olarak kabul edip, bunlara kıyâs-1 celî, kıyas-ı evla, kıyas fî ma'nel-asl, kıyas mea' nefyi'l-farık diyenlere karşı, bunları delalet bağlamında değerlendirip nassın delaleti, fahve'l-hitâb, lahne'1-hitâb ya da mefhumü'l-muvâfaka olacumhuriget theology journal 2o, no. 1 (June 2016): 61-88. 
Dikkat edilirse iki öncül kat'î olduğunda kıyastaki kat'îlik, kıyasın bilgi değerindeki kat'îlik olmayıp, illetin asıl ve fer'de bulunma kat'îliğidir. ${ }^{57}$ Dolayısıyla bu durumun kıyasın bilgi değerini etkilemesi söz konusu değildir. Aslında İsnevî'nin de işaret ettiği gibi söz konusu hükümlere k1yas yoluyla ulaşıldığının kabul edilmesi halinde bu türlü kıyaslar her ne kadar kesin kıyas olarak kabul edilse de, kıyasla ulaşılan bu sonuç/hüküm, müçtehidin ameli ile elde edildiği için yine zannîdir. ${ }^{58}$

Asılda tespit edilen illet kesin olmadığında ya da asılda tespit edilen illet kesin olduğu halde fer'de bu illetin varlığ 1 kesin değilse ya da hem asılda hem de fer'de illetin varlığı kesin değilse bu durumdaki kıyasın zan ifade edeceğinde ise ittifak vardır. ${ }^{59}$

Şafî̂ usûlcülerin yaptığı kategorik ayırım dikkate alınmış olsa dahi kıyasın bilgi değerinin zan olduğu noktasında ittifak sağlandığı anlaşılmaktadır. Zira usûlî/şer'î kıyas; bir mukayese ve yakınlaştırma işlemidir. Kıyas yapan kişi yeni bir hüküm icat etmez veya önermelerden bir netice çıkarmaz. Aksine aslın hükmünü fer'e uygulamakla yetinir ki bu da kıyas yapanın "hükmün illeti şudur" şeklindeki zannına dayanır. Dolayısıyla elde edilen bilgi yakînî değil, zannî bir bilgidir. ${ }^{60}$

\section{KIYASIN AMELÎ DEĞERI}

Kıyasla elde edilen bilginin zannî bilgi olduğunda ittifak sağlanınca, zannî bilginin ne olduğu ve mükellefiyet oluşturmadaki rolü tartışılmıştır.

Bilgide kesinliği ifade etmek üzere kullanılan yakîn terimine karşılık zan, şek (şüphe-rayb), vehim gibi terimler de bilgide kesinliğe yaklaşı-

rak isimlendirenler de bulunmaktadır. Geniş bilgi için bk. Hamd b. Hamdi Saidî, Muvazene Beyne Delaleti'n-Nas ve'l-Kıyasi'l-Usûl ve Eseru Zalike ale'l-Furû'i'l-Fıhiyye (Kahire: Dârü'l-Harir li't-Tıbaa, 1993), 1: 298; Muhammed Edip Salih, Tefsirü'n-Nusûs fi'l-Fıkhi'lİslâmî (Beyrut: el-Mektebetü'l-İslamiyye, 1993), 1: 638.

57 Mennun, Nibras, 1: 180

58 İsnevî, Nihayetü's-Ŝ̂'l, 4: 27.

59 İsnevî, Nihayetü's-Ŝे'l, 4: 27.

60 Muhammed Abid Cabirî, Arap-İslam Kültürünün Akıl Yapısı: Arap-İslam Kültüründeki Bilgi Sistemlerinin Eleştirel Bir Analizi, çev. Burhan Köroğlu, v.dğr. (İstanbul: Kitabevi, 1999), 188.

cumhuriget ilahigat dergisi 20, sy. 1 (Haziran 2016): 61-88. 
lan veya uzaklaşılan durumları ifade etmek üzere kullanılır. Özellikle Fahreddin Râzî sonrası kelamcılar yakîni, "hakikatle örtüşen, şüphe ve taklitten uzak olan bilgi" ${ }^{61}$ olarak tanımlamıştır. Fıkıh ilminde ise daha ziyade "kat'î delile dayanarak kesinliğe ulaşma" 62 veya "bir şeyin varlık veya yokluğunu kesin olarak veya zann-1 galib ile bilme",63 "kendisinde tereddüt olmayan bilgi" 64 şeklinde tanımlanmıştır. Bu tanımlardan anlaşılacağ 1 üzere; Kelam ilminde sadece tereddüt ve şüpheden uzak olan kesin bilgi yakîn olarak isimlendirilmişken, Fıkıh ilminde ise, İbn Nüceym ve Ali Haydar Efendinin yakîn tanımlarından da anlaşıldığ ${ }_{1}$ gibi, ${ }^{65}$ râcih veya galip bilgi de bazı durumlarda yakîn olarak kabul edilmiştir. ${ }^{66}$ Hatta özellikle Hanefî usûlünde kesin bilgi, özel anlamda kesinlik (el-kat' bi'l-ma'nâ'lhass)* ve genel anlamda kesinlik (el-kat' bi'l-ma'nâ'l-âmm) ${ }^{* * *}$ olarak kısımlandırılmış ve bilgi değeri "ilm-i tume'nîn" olarak isimlendirilen genel anlamdaki kesinlik, kat'î bilgi içerisinde değerlendirilmiştir. ${ }^{67}$

61 Seyid Şerif Cürcânî, et-Tarifât (Mısır: Matbaatü Mustafa el-Babî el-Halebî, 1938), 231; Tahânevî, Keşşâfi Istılahâti'l-Fünûn, 2: 1812; Ahmed Zerkâ, Şerhü'l-Kavâ'idi'l-Fıkhiyye (Beyrut: Dârü'l-Garbi'l-İslâmî, 1983), 79; Osman Demir, "Yakin", Türkiye Diyanet Yayınları, 43, (Ankara: TDV Yayınlar1, 2013), 271-273.

62 Ahmed b. Muhammed Hamevî, Gamzu Uyûni'l-Basâir: Şerhu Kitâbi'l-Eşbâh ve'n-Nezâir (Beyrut: Dârü'1-Kütübi'1-İlmiyye, 1985), 1: 193.

63 Ali Haydar, Dürerü'l-Hükkâm Şerhu Mecelleti'l-Ahkâm, ta'rib. Fehmi el-Hüseynî (Beyrut: Dâru'l-Cîl, 1991), 1: 22.

64 Ali Haydar, Dürerü'l-Hükkâm, 1: 22; Zerkâ, Şerhü'l-Kavâ'id, 79. Farklı anlamları için bk. Cürcânî, Tarifat, 231.

65 Zeynü'l-Abidin İbn Nüceym, el-Eşbah ve'n-Nezâir, Gamzu Uyûnî'l-Besâir birlikte (Beyrut: Dârü'l-Kütübi'illmiyye, 1985), 1: 241; Ali Haydar, Dürerü'l-Hükkâm, 1: 22.

66 Fıkıhta bu durum şu şekilde sistematize edilmiştir. Eğer zann-1 galip geçerli bir delilden elde edilmiş ise, kendisi üzerine hüküm bina edilmesi açısından yakîn mesabesindedir. Örneğin abdestin bozulduğunda tereddüt edildiğinde abdestin varlığına hükmetmek, namazın rekât sayısında tereddüt edildiğinde zann-1 galibe göre amel edilmesi gibi. Bk. İbn Nüceym, Eşbah, 1: 241; Muhyiddin Nevevî, el-Mecmu' Şerhu'l-Mühezzeb, thk. Muhammed Bahît el'Mutî (Cidde: Mektebetü'l-İrşad, ts.), 1: 240; Ahmed Makarrî, el-Kavaîd, thk. Ahmed b. Abdullah, (Mekke: Merkezü İhyai't-Türasi'l-İslamî, ts.), 1: 289-295.

* Asla başka ihtimale açık olmayan muhkem ve müfesser lafızlardan elde edilen bilgi böyledir.

${ }^{* *}$ Kendi manasından başka manaya ihtimali olan, fakat bu ihtimal hakkında delilin bulunmadığı has, amm, zahir, nass lafızlardan elde edilen bilgi böyledir.

67 Bk. Sadrüşşerîa, Tavzîh, 1: 35; Teftazanî, Şerhü't-Telvih, 1: 35; Tahânevî, Keşşâfı Istılahâti'lFünûn, 2: 1333; Zekiyyüddin Şaban, Usûlu'l-Fıkhı'l-İslâmî (ts: yy. ), 296.

$$
\text { cumhuriget theology journal 2o, no. } 1 \text { (June 2016): 61-88. }
$$


Kelamcilara göre zan; "ihtimal dahilinde bulunan iki hükümden doğruya daha yakın görülen", vehim ise; "ikinci derecede görülendir." Şek ise; "biri diğerinden daha güçlü olmayan iki hükmün doğru olabileceğini düşünmektir." 68 Fikıhçllara göre zan; "doğruluğu ve yanlışlığı eşit derecede mümkün görülen veya biri diğerine tercih edilebilen," ${ }^{69}$ şek ise; "bir şeyin o şey olduğuna inanmada kalbin mutlak kararsızlık hali"70 ya da zan manasında "doğruluğu ve yanlışlığı eşit derecede mümkün görülen veya biri diğerine tercih edilebilen bilgidir." 71 Usûlcülere göre ise, iki taraf birbirine eşit olduğunda şek, eşitlik bozulduğunda ağır basan (râcih) taraf zan, diğer (mercûh) taraf vehimdir.72

Şema halinde şöyle gösterebiliriz.

\begin{tabular}{|c|c|c|c|}
\hline \multicolumn{2}{|c|}{ Kelamcılara Göre } & Fıkıhçlara Göre & Usulcülere Göre \\
\hline YAKîN & Kesin bilgi & $\begin{array}{c}\text { Kesin bilgi veya râcih/ga- } \\
\text { lip bilgi }\end{array}$ & Kesin bilgi \\
\hline ZAN & $\begin{array}{c}\text { Doğruya yakın } \\
\text { olan bilgi }\end{array}$ & $\begin{array}{c}\text { Doğruluğu ve yanlışlı̆̆ı } \\
\text { eşit olan veya doğruluğu } \\
\text { tercih edilen bilgi }\end{array}$ & $\begin{array}{c}\text { Doğruya yakın olan } \\
\text { bilgi }\end{array}$ \\
\hline ŞEK & $\begin{array}{c}\text { İki tarafı eşit } \\
\text { olan bilgi }\end{array}$ & $\begin{array}{c}\text { Doğruluğu ve yanlışı̆̆ı } \\
\text { eşit olan veya doğruluğu } \\
\text { tercih edilen bilgi / Kalbin } \\
\text { mutlak karasılılı hali }\end{array}$ & İki tarafı eşit olan bilgi \\
\hline VEHIM & $\begin{array}{c}\text { Yanlışa yakın } \\
\text { olan bilgi }\end{array}$ & Yanlışa yakın olan bilgi & Yanlışa yakın olan bilgi \\
\hline
\end{tabular}

Buna göre, fukaha kesin veya râcih olan bilgiye yakîn terimini kullandıkları gibi, mahiyeti itibariyle şek kabilinden olanlara da zan terimini kullanmışlardır. Çünkü onlar, varlık ve yokluk ihtimallerinin eşit olması veya bu ihtimallerden birinin ağır basması durumunu dikkate almadan

68 Tahânevî, Keşşâfi Istılahâti'l-Fünûn, 2: 1153.

69 Tahânevî, Keşşâfi Istılahâti'l-Fünûn, 2: 1153; Hamevî, Gamzu Uyûni'l-Basâir, 1: 193; Nevevî, Mecmu', 1: 220.

70 Hamevî, Gamzu Uyûni'l-Basâir, 1: 193; Ali Haydar, Dürerü'l-Hükkâm, 1: 22; Zerkâ, Şerhü'lKavâ'id, 80.

71 Hamevî, Gamzu Uyûni'l-Basâir, 1: 193, 240-241; Nevevî, Mecmu', 1: 22.

72 Nevevî, Mecmu', 1: 220.

$$
\text { cumhuriget ilahigat dergisi 2o, sy. 1 (Haziran 2016): 61-88. }
$$


zan terimiyle bir şeyin varlığı ile yokluğu arasındaki tereddüt durumunu kastetmişlerdir. ${ }^{73}$

Bu farklı yaklaşımların sonucu olarak özellikle kelamcılarının büyük ekseriyeti yakîn karşıllğında "itikad" kelimesini kullanmak suretiyle yakîni, itikadın sıfatı olarak görme eğilimlerini ortaya koyarak yakîn ifade eden durumun oluşmasını "şekk" in bulunmama şartına bağlamışlardır. ${ }^{74}$ Böylece inanç esaslarını tespit etme, açıklama ve savunma amacını güden Kelam ilminde prensip olarak ihtimalli bilgi delil olarak kabul edilmemiştir. Fıkıh Usûlü'nde ise, doğruluk ihtimali baskın bilgi/ilm-i galib-i zan, kesin olmayan bilgi kaynakları arasında ve bir içtihat yöntemi olarak kabul edilmiştir. ${ }^{75}$ Yani kelamcılar ve fıkıhcılar bilgiyi; doğruluğu hakkında kesin kanaat sahibi olduğumuz ideal bilgi (yakîn) ve kesin olmayan bilgi anlamında kullanmıs, ${ }^{76}$ kesin bilgi, bilgi üretmede kelam ile fıkıh ilminde eşit görülse de, ideal anlamda kesin bilgi üretmeyen kıyas, haber-i vahid ve müevvel ayet ile amel edileceği konusu fıkıhçılar tarafından kabul edilmiştir. ${ }^{77}$ Zira amelî konularda sadece kesin bilgi ile yetinilmiş olsaydı içtihattan söz edilemezdi. Çünkü içtihatla ulaşılan bilgi kesin bilgi değil, zannî bilgidir. ${ }^{78}$

Kesinlik taşımayan bu bilginin mükellefiyet oluşturmadaki rolünü cevaplandırmada usulcüler, ilim ile amel arasında ayırım yapmıştır. ${ }^{79} \mathrm{Bu}$ ayırımdan yola çıan usulcüler, zann-1 galib derecesinde elde edilen bilgi ile kişinin mükellef olacağı görüşündedir. ${ }^{80}$ Bu konuda Cessâs, mükellefin amel etmesi açısından râcih olan zan, kesin bilgi gibidir; ${ }^{81}$ Ebû Ya'la (ö.

73 İbn Nüceym, Eşbah, 1: 240-241; H. Yunus Apaydın, "Zan", Türkiye Diyanet Vakfı İslam Ansiklopedisi, c. 44, (Ankara: TDV Yayınları, 2013), 122. Ayrıca zannın yakîn anlamında kullanımı için bk. Tahânevî, Keşşâfı Istılahati'l-Fünun, 2: 1154.

74 Seyyid Şerif Cürcânî, Şerhu'l-Mevakıf, Çelebî ve Siyalkutî haşiyesi ile birlikte (Kum: İntişarat-1 Şerif er-Radî, 1907), 1: 199; Yakîn kelimesinin kullanımı için bk. Cağfer Karadaş, "Yakin ve İtikad", Uludağ Üniversitesi İlahiyat Fakültesi Dergisi, 10, sy, 1, (2001): 113-126.

75 Murtaza Bedir, Sünnet: Hz. Peygamber'in Evrensel Mesajı (İstanbul: İsam yay. 2006$), 75$.

76 Tahânevî, Keşşâfı Istılahâti'l-Fünûn, 2: 1219-1220.

77 Debûsî, Takvîmu'l-Edille, 104, 106; Serahsî, Usûl, 2: 141; Nesefî, Keşfu'l-Esrar, 2: 122.

78 Cessâs, el-Fusûl, 3: 92; Âmidî, el-ïhkâm, 4: 206.

79 Buhârî, Keşfü'l-Esrar, 1: 75; Sem'ânî, Kavâdr', 4: 66-67.

80 Cessâs, el-Fusûl, 4: 82; Debûsî, Takvîmu'l-Edille, 272; Serahsî, Usûl, 2: 140; Zerkeşî, elBahrü'l-Muhît, 1: 75, 125.

81 Cessâs, el-Fusûl, 3: 90, Nesefî, Keşfu'l-Esrar, 2: 11. cumhuriget theology journal 20, no. 1 (June 2016): 61-88. 
458/1066), zan hükme ulaşma yollarındandır; 82 Şîrâzî (ö. 476/1083) kesin bilgiyi elde etme imkanı olsa da zann-1 galip ile hükmetmenin cevazı mümteni değildir,;3 Sem’ânî (ö. 489/1096) de, hükümler zann-1 galip ile sabit olur ${ }^{84}$ diyerek zannî bilgi ile amel edileceğini açıkça ifade etmiştir. Hatta İbn Berhân (ö. 518/1124), ${ }^{85}$ Semerkandî (ö. 539/1144), ${ }^{86}$ Gazzâlî̀ ${ }^{87}$ ve Lâmişî (ö.6. yy.) ${ }^{88}$ gibi birçok usûlcü, bu bilgi ile amel etmenin şer'an vacip olduğunu zikretmiştir. Razî'ye göre de, dini konularda kıyasın delil olması her ne kadar tartışmalı dahi olsa, müçtehidin kıyasla ulaştığı hükümle amel etmesi ve ona göre fetva vermesi gerekir. ${ }^{89}$ Şâtıbî (ö.790/1388) de, furû f1kıhta zannî delillerin (amel bakımından) kat'î delil mesabesinde olduğuna dair kesin delillerin mevcut olduğunu, ${ }^{90}$ hüküm açısından kat'î ve zannî delil arasında herhangi farkın mevcut olmadığını, ancak delillerin tearuzu durumunda bu farklılığın ortaya çıkacağını belirtmektedir. ${ }^{91}$

Usûlcüler, zannî bilgi ile amel edilmesinin gerekliliğini birçok naklî ve aklî delile dayandırmışlardır. ${ }^{92}$ Şöyle ki; naslarda bazen ilim kelimesi zann-1 galip ve kanaat anlamında kullanılmış ve bu bilgi ile amel edilmesi istenmiştir. Örneğin Bakara suresinde, "(Bu koca da) onu boşadığ takdirde, onlar (her iki taraf da) Allah'ın sinırların muhafaza edeceklerine inandıkları/zannettikleri takdirde, yeniden evlenmelerinde beis yoktur...,93 Mümtehine suresinde, "Ĕ̆er onların mümin olduğunu bilirseniz..."94 ayetlerinde zahiren elde

$82 \quad$ Ebu Ya'la, el-Udde, 1: 83; 3: 872.

83 Şirâzî, Şerhu'l-Lüma', 2: 1090.

34 Sem'ânî, Kavâdı', 2: 98, 4: 67-68.

85 Ebü'l-Feth İbn Berhân, el-Vüsûl ile'l-Usûl, thk. Abdülhamîd Ali Ebû Züneyd (Riyad: Mektebtü'1-Mearif, 1984), 2: 239-241.

86 Abdulmelik Abdurrahman Esad es-Saîdî, "Mizanü'l-Usûl fi Netâicu'l-Ukûl Dirase, Tahkik ve Ta'lik" (Doktora Tezi, Ümmü'1-Kurra Üniversitesi), 2: 841.

87 Gazzâlî, Mustasfâ, 3: 506.

88 Ebü's-Sena Lâmişî, Kitâb fî Usûli'l-Fıkh, thk. Abdülmecid Türkî (Beyrut: Dârü'l-Garbi'lİslâmî, 1995), 182; Gazzâlî, Mustasfâ, 3: 506.

89 Razî, Mahsûl, 5: 20.

90 Ebû İshak Şatıbî, el-Muvafakât fi Usûli'ş-Şerîa, şrh. Abdullah Dıraz (Beyrut: Dârü'1-Kütübi'l-İlmiyye, 1991), 2: 273.

91 Şatıbî, Muvafakât, 2: 273; 1: 253-255.

92 Deliller için bk. Sa'd b. Nasır Şeşerî, el-Kat' ve'z-Zan inde'l-Usûliyyin: Hakikatuhuma ve Turuku İstifadetihima ve Ahkamuha (Riyad: Darü'1-Hubeyb, 1997), 2: 505-507.

93 Bakara $2 / 230$

94 Mümtehine 60/10. cumhuriget ilahigat dergisi 20, sy. 1 (Haziran 2016): 61-88. 
edilen bilgi/zan, ilim olarak isimlendirilmiş ve bu bilgiye göre amel edilmesi istenmiştir. Yine Yusuf suresinde "Şüphesiz senin oğlun çaldr. Biz ancak bildiğimize şahitlik ederiz"95 ayetinde de işin iç yüzüne vakıf olmadıkları bilgi, ilim olarak isimlendirilmiştir.

Yine sünnette zannî bilgi ile amel edileceğine dair birçok delil mevcuttur. Örneğin Ümmü Seleme'den gelen bir rivayette, Hz. Peygamber kapısının önünde gürültü işitmiş, yanlarına çıkmış ve: "Ben ancak bir insanım! Bana gerçekten davacılar geliyor. Mümkündür ki bazınız (haksız olduğu halde) savunmasını (karşı taraftan) daha iyi yapabilir ve ben de onu doğru zanneder ve lehine hüküm vermiş olabilirim. Her kime bir müslümanın hakkını hükmetmişsem bu ancak ateşten bir parçadır. Onu (isterse) alsın yahut (dilerse) terk etsin"96 Yine Hz. Peygamber, "Hiç kimse Benî Kurayza'ya varmadan ikindi namazını kılmasın' diye ilan ettirmiş, hedefe varmadan ikindi namazının vakti daralınca sefere iştirak eden ashap iki kısma ayrılmış; bir kısmı "bu sözden maksat oraya bir an önce yetişmemizdir; yoksa ikindi namazının vakti içinde kılınmaması değildir" demiş, diğer kısım ise, "oraya varmadan ikindi namazı kılınmaması emredildi, vakit çıksa bile biz yolda kılmayız demiştir. Daha sonra olay Hz. Peygamber'e aktarıldığında her iki görüşü de onaylamıştır. ${ }^{97}$ Bu rivayetler zannî bilgi ile amel edilebileceğine açıkça delil olmaktadır. Ayrıca bu konuda yani zannî bilgi ile amel etme hususunda sahabe icmaı'da delil olarak ileri sürülmüştür. ${ }^{98}$

Nasların ibare, işare, iktiza ve delaletleriyle her şeyi kuşattığını ileri süren Zahirilerin,99 zannın yerilmiş olduğuna dair ileri sürdükleri "Allah

95 Yusuf 12/81.

96 Müslim, Kitabü'l-Akdiye, 5 .

97 Buhârî, Meğazî, 30.

98 Gazzâlî, Mustasfâ, 3: 507-519; Âmidî, el-İhkâm, 3: 359; Buhârî, Keşfü'l-Esrar, 3: 413-414.

99 Zahirilerin görüşleri için bkz. Ebu Muhammed İbn Hazm, el-İhkâm fî Usûli'l-Ahkâm, thk. Ahmed Muhammed Şakir (Beyrut: el-Afakü'l-Cedide, 1983) 7: 53-204. cumhuriget theology journal 2o, no. 1 (June 2016): 61-88. 
hakkında gerçek bilgiden başka şey söylemeyin",100 "Zan gerçekten bir şey gider$m e z^{\prime \prime 101} \mathrm{vb}$. ayetler yukarıdaki naslarla çelişmemektedir. ${ }^{102}$ Zira bu ayetlerde ve diğer nasslarda yerilen zan, itikadî konularla ilgili ${ }^{103}$ ya da vehim, şüphe, heva ve hevese uyma anlamındadır. ${ }^{104}$ Hâlbuki kıyasla elde edilen bilgi ise bu anlamları ifade etmemektedir. Ayrıca fukahanın ifade ettiği gibi kıyas, nasstan bağımsız olmayıp, nassa tabi olarak, hakkında nassla haber verilmiş bir şey bulunmayan bir meseleyi o nassa kıyas ederek onun hakkında kıyas yoluyla söz söylemektir. ${ }^{105}$ Zira hükümler ya lafız itibarı ile ya da mana itibariyle nasslarda mevcuttur. Kendisine kıyas yapilacak aslın hükmü lafzen, kıyasa konu olan fer'in hükmü ise mana olarak nassta vardır. Kıyas yapan, kendisinden yeni bir hüküm ortaya koymadığı gibi hüküm de icat etmez; sadece aralarında kıyası meşru kılan benzerliği görmesiyle, aslın hükmünü fer'e uygular. Aslında "kiyas müsbit değil, muzhirdir" sözü de tam bunu vurgulamaktadır. Ayrıca bir vasfın illet olması için o vasfın dinin genel çerçevesiyle uygunluğu noktasında mülâemet", te'sîr" ve münasib**** olma gibi şartların ${ }^{106}$ aranması da kıyasın rastgele bir aklî muhakeme olmadığının en açık göstergesidir.

Şunu da belirtmeliyiz ki; müçtehitlerin aynı kıyasla farklı sonuçlara ulaşması da kıyasla elde edilen bu bilgiyle amel etmeyi problemli hale getirmez. Bu durum, bir bakıma şahitliği bir hâkim tarafından kabul edilen

$100 \quad$ Nisa $4 / 171$.

101 Yunus 10/36.

102 Cessâs, el-Fusûl, 3: 92.

103 Ebu Abdullah Kurtubî, el-Camiu' li Ahkami'l-Kur'an (Riyad: Daru Alemi'l-Kütüb, 2003), 8: 343 .

104 Abdülvahhab Hallaf, İlmü Usûli'l-Fıkh (İskenderiyye: Mektebetü'd-Daveti'l-İslamiyye, 2002), 59-60.

105 Şafîi, Risale, 507-508; Debûsî, Takvîmu'l-Edille, 272

*Vasfin Hz. Peygamber ve seleften nakledilen vasıflara uygun olması ya da vasfın cinsinin hükmün cinsinde müessir olmasi.

${ }^{* *}$ Vasfın etkisinin hükmün cinsinde ortaya çıkması.

*** Vasfın ortaya çıkardığ 1 hükmün şer’î maslahatlara uygun olması.

106 Konuyla ilgili farklı yaklaşımlar için bk. Debûsî, Takvîmu'l-Edille, 304; Serahsî, Usûl, 2 : 177; Gazzâlî, Mustasfâ, 3: 629; a. mlf., Şifaü'l-Ğalil (Beyrut: 1999), 71 vd. Farklı yaklaşımların değerlendirilmesi için bk. Temel Kacır, "Hanefi Usulcülerinden Kadı Ebû Zeyd Debûsî'nin Kıyas Nazariyesi (Takvimü'l-Edille Adlı Eseri Çerçevesinde)" (Yüksek lisans tezi, Gazi Üniversitesi), 76-82.

$$
\text { cumhuriget ilahigat dergisi 20, sy. 1 (Haziran 2016): 61-88. }
$$


Usûlî Kıyasın Bilgi ve Amel Değeri | 81

kişinin diğer hâkim tarafından şahitliğinin reddedilmesine benzer. Zira birinci hâkimin muttali olamadığı bazı konulara diğer hâkim muttali olabilir. Kıyasta da aynı nass üzerinden bir müçtehidin tespit edemediği illeti diğer müçtehit tespit edebilir. Hz. Peygamber' in "Bir hâkim hükmünü verirken içtihat eder ve isabet ederse ona iki ecir vardır. İçtihadında hata ederse ona bir ecir vardır"107 hadisinde, elde edilen bilginin farklılığına rağmen içtihadın teşvik edildiği anlaşılmaktadır. Yine bu hadis müçtehidin, Allah katındaki hükme ulaşmakla değil, ancak içtihadıyla elde ettiği zan ile mükellef olduğunu da ortaya koymaktadır. ${ }^{108}$

Zannî bilgi ile amel etme konusunda haber-i vahide de atıf yapan usûlcüler, bilgi değeri kesin olmayan haber-i vahid ${ }^{109}$ nasıl ki amelî hükümler için yeterli ise kıyasla ulaşılan bilgi de aynı şekilde amelî hükümler için yeterlidir diyerek bir mukayese yapmışlardır. ${ }^{110}$ Şöyle ki; haber-i vâhidin bize intikalinde şüphe bulunmasına rağmen, özünde Hz. Peygamber'e ait oluşundan dolayı bilgi ifade eder. Aynı şekilde bizce tespit edilen vasfın, kıyasa konu olan hükmün illeti olma ihtimal ve şüphesini barındırmasına rağmen; söz konusu illet Allah katında sabit olduğu için kıyas da bilgi ifade eder. Kıyastaki ta'lîl, ravinin rivayetine; vasıf ise habere benzer. Rivayette hata ihtimali olabildiği gibi müctehidin ta'lîlinde de hata ihtimali bulunabilir. Usûlcüler haber-i vahid ile kıyas arasındaki bu benzerliğe dayanarak, kıyasın da haber-i vahid gibi zannî bilgi ifade ettiği, dolayısıyla kendisiyle amelin gerekli olduğu sonucuna ulaşmışlardır. ${ }^{111}$

Yine usûlcüler, ictihad ve rey-i gâlib vasıtasıyla müşterek lafzın muhtemel bulunduğu manalardan birinin tercih edilmesi anlamındaki müevvel lafzın hata ve ihtimal özelliklerini taşımasına rağmen amel etmeyi gerektirmesinden; tahsisten sonra geride kalan fertlerine delaleti

107 Buhârî, İtisam, 20-21.

108 Şafî̀, Risale, 493-497.

109 Buhârî, Keşfü'l-Esrar, 2: 538; Âmidî, el-İhkâm, 2: 44.

110 Cessâs, el-Fusûl, 1: 166; Buhârî, Keşfü'l-Esrar, 2: 540.

111 Debûsî, Takvîmu'l-Edille, 273; Serahsî, Usûll, 2: 141; Sem'ânî, Kavâdı', 2: 71; Nesefî, Keşfu'lEsrar, 2: 122. Kıyası delil kabul etmeyenler, haber-i vahid ile müevvel ayetin bilgi değerini kıyastan farklı değerlendirmişlerdir. Onlara göre haber-i vahid ile müevvel ayet aslı itibariyle kat'î, kıyas ise aslı itibariyle ihtimallidir. Bk. Sem'ânî, Kavâdı', 2: 74; Buhârî, Keşfü'lEsrar, 4: 498, Nesefî, Keşfu'l-Esrar, 2: 121.

$$
\text { cumhuriget theology journal 2o, no. 1 (June 2016): 61-88. }
$$


zannî olan umûm lafzın, bu ihtimaline rağmen, amel için yeterli kabul edilmesinden hareketle kiyasta da illetin tespitinden kaynaklanan hata ve ihtimale rağmen ulaşılan hükmün amel için yeterli olduğu sonucuna ulaşmışlardır. ${ }^{112}$

Ayrıca ittifakla kabul edilen tahkîku'l-menât ${ }^{113}$ yönteminin bir çeşidi de, zannî bilginin delil olduğunu gösterir. Zira fakihin, karşılaştığı her bir hukukî olayı inceleyip buna göre hüküm vermesi gerekir. Bu hüküm de zanna dayanır. Bundan kaçınmak da mümkün değildir. Örneğin “Ey iman edenler! İhramda iken avlanmayınız. Sizden kim kasten av hayvanını öldürürse onun cezası, öldürdüğü hayvanın dengi olduğuna iki adil kişinin karar verdiği ehlî bir hayvanı kurban edilmek üzere Kabe'ye göndermesidir..."114 ayetinden öldürülen av hayvanın mislinin vacip olduğu nassla, bu hayvanının ehlî hayvana denkliğinin tespiti ise içtihat ile olacağ 1 anlaşılmaktadır. Şâri' adil şahitlerin şahitliğine dayanarak hüküm vermeyi emretmiş, şahitlerin adaleti ise ancak zannî olarak anlaşılabilir. Çünkü zahiren adil görünen insanların da yalan söyleme ihtimali mevcuttur. Bu ihtimale rağmen şâri', şahitlerin adil olduğu yönündeki zannı muteber sayıp adil olduğu zannedilen kimselerin şahitliğine dayanılarak hüküm verilmesini istemiştir. Yine namaz vakitlerinin tahakkuk edip etmediği, kıblenin tespiti, zekâtın sarf yerlerinden her birinin tanımı, kapsamı, akrabalara kifayet miktarı nafaka takdir edilmesi vb. hükümlerin hepsi zannî olarak tespit edilir. ${ }^{115}$

Kıyas ile elde edilen zannî bilgiyle amel etmenin gerekliliğini temellendirmede kullanılabilecek başka bir argüman da, "içtihatta isabet ve hata" meselesi ile ilgili görüşlerdir. Ehlinden sadır olması şartıyla her içtihadın doğru sayılacağını kabul eden "musavvibe" görüşüne göre, ictihadî meselede içtihat öncesinde kesinlikle muayyen bir hüküm yoktur. Hüküm ancak müctehidin zannından ibarettir. Bu nedenle ictihadî meselede farklı

112 Debûsî, Takvîmu'l-Edille, 269; Nesefî, Keşfu'l-Esrar, 2: 122; Sem'ânî, Kavâdı', 2: 68; Gazzâlî, Mustasfâ, 3: 565; Âmidî, el-İhkâm, 4: 25.

113 Tahkîku'l-menât ya hükmün, bazı emarelere dayanarak istidlal yoluyla olaylara tatbiki ya da illeti nass veya icma ile ortaya konmuş bir hükmün, aynı illeti taşıdığı sonucuna içtihat ile varılmış başka bir mesele hakkında geçerli kılınması anlamındadır. Burada kastedilen tahkîku'1-menâtın birinci kısmıdır. Bk. İbn Kudâme, Ravza, 2: 229-231.

114 Mâide 5/95.

115 Gazzâlî, Mustasfâ, 3: 485-487, 506; Apaydın, "Zan", 123.

$$
\text { cumhuriget ilahigat dergisi 2o, sy. 1 (Haziran 2016): 61-88. }
$$


içtihat sayısınca doğru mevcuttur ve hepsi Allah katında eşit düzeydedir ve her müçtehit içtihadında isabet etmiştir. İctihadî meselede muayyen şer'î bir hükmün varlığını ve doğrunun tek olduğunu kabul eden "muhattıe" görüşüne göre ise, anılan hükme hangi müçtehit isabet etmişse o doğru, diğerleri hatalıdır. Hüküm müçtehidin zannından ibaret de değildir. Muayyen bu hükme delâlet eden bir delilin varlığı ve mahiyeti hakkında ise farklı görüşler mevcuttur. ${ }^{116}$

Kıyas ile elde edilen bilgi musavvibe'nin görüşüne göre bir sorun teşkil etmezken, muhattıe' nin görüşü ile tezat teşkil eder ${ }^{117}$ gibi durmaktadır. Fakat daha dikkatli bir inceleme yaptığımızda bu görüşe göre de bir sorun teşkil etmediği anlaşılmaktadır. Şöyle ki; Allah katında belirli olan bir şer'î hüküm, bizce yakînen bilinemediğinden hangi müçtehidin doğru hangisinin hatalı olduğu kesin olarak söylenemez. Bu durumda hükmün aranmasını yeterli kabul eden muhattıe'den bir görüşe göre; müçtehidin kendi üzerine düşen sorumluluğu yerine getirmesi, hükümde isabet etmesi anlamındadır. ${ }^{118} \mathrm{O}$ halde kıyasla ulaşılan bilgi, bu görüşe göre de bir sorun teşkil etmemektedir. Muhattıe'den muayyen hükme isabet etmeyi zorunlu kabul eden diğer görüşe göre ise; kıyasın dini meşrûiyeti sahabenin karşılaştıkları ve hakkında nas bulamadıkları her meselede, içtihat ve reyle hüküm vermede icma etmelerine ve bunun da bize kadar şüphe bulunmayan bir tevatürle gelmiş olmasına dayanmaktadır. ${ }^{119}$

Yine hem muhattie hem de musavvibe'ye göre, her ne kadar kıyasla ulaşılan hüküm/sonuç hakkında şarî'in saraheten hitâbı bulunmasa da, delaleten hitâbının varlığı kabul edilir. ${ }^{120}$ Müçtehit de delaleten varlığ kabul edilen bu hükme ulaşmakla mükelleftir. Zira hakkında nas olmayan konularda müçtehidin sorumluluğu, kendince zahiren doğru olanı bulmaktır,

116 Teftâzânî, et-Telvîh, 2: 118-119; Âmidî, el-ïhkâm, 4: 221-222; Zerkeşî, el-Bahrü'l-Muhît, 6: 241-251; H. Yunus Apaydın, "İçtihad", Türkiye Diyanet Vakfı İslam Ansiklopedisi, c. 21, (Ankara: TDV Yayınları, 2000),440-442. Geniş bilgi için bk. Rahmi Telkenaroğlu, İçtihatta İsabet ve Hata Meselesi (Ankara: Türkiye Diyanet Vakfı Yayınları, 2011).

117 Gazzâlî, Mustasfâ, 3: 498.

118 Ebü'l-Hüseyin Basrî, el-Mu'temed fì Usûli'l-Fıkh, thk. Muhammed Hamidullah (Dımaşk: el-Ma'hadü'l-İlmî el-Fransî li'd-Diraseti'l-Arabiyye, 1964), 2: 949-954, 987-988; Âmidî, elİhkâm, 4: 221-222; Debûsî, Takvîmu'l-Edille, 407.

119 Cabirî, Arap-İslam Kültürünün Akıl Yapısı, 187.

120 Seyid Bey, Medhal (İstanbul: Matbaa Amiriyye, 1333), 213-214; Gazzâli, Mustasfâ, 4: 85. cumburiget theology journal 20, no. 1 (June 2016): 61-88. 
yoksa gaybı bilmek değildir. ${ }^{121}$ Ayrıca müçtehit, ilahi iradeyi anlama çaba ve gayretini göstererek bu sonuca ulaştığı için elde edilen hüküm, sonuç itibariyle şer'îlik vasfını taşımaktadır. Bu nedenle kıyas, şer'î delillerin dördüncüsü olarak kabul edilmiş ve elde edilen bu hüküm ile amel edilmesi gerekli görülmüştür.

\section{SONUÇ}

Kıyasın bilgi ve amel değeriyle ilgili yapmış olduğumuz bu çalışmadan sonra diyebiliriz ki, illet tespitindeki farklılıklar nedeniyle kıyasla elde edilen sonucun farklı olması, ayrıca kıyasla ulaşılan bilginin zan ifade etmesi dikkate alındığında her zaman kıyasa yönelik itirazların olabileceği anlaşılmaktadır. Ancak sınırlı olan naslarla sınırsız olayları çözüme kavuşturmak zor, hatta imkânsızdır. Bu nedenle aslî kaynaklardan ve dini meseleleri hükme bağlama vasıtalarından biri olarak kabul edilen kıyas, tarihi süreç içerisinde kullanıldığı gibi yeni problemlerin çözümünde de kullanılmaya devam edecektir. Hatta bu konuda kıyasın delil ya da metot olarak değerlendirilmesi de durumu değiştirmeyecektir.

Fukahanın "kıyas muzhirdir, müsbit değildir" sözünden de anlaşıldığı üzere, usûlî kıyas, ibtidaen hüküm koyma anlamında olmadığı gibi, nasslardan bağımsız ve nasslara alternatif bir delil de değildir. Aksine nassların anlam boyutunda var olanı ortaya çıkaran ve lafızda mevcut olan anlamı genişleten bir yöntemdir. Kıyas yapan kişi sadece kıyası meşru kılan benzerliği görmesiyle, aslın hükmünü fer'e uygular. Bu uygulamada yani asıldaki illetin tespiti ve tespit edilen bu illetin fer'e uygulanmasında en önemli etken müçtehidin zannıdır. Bundan dolayı kıyas yoluyla elde edilen bilginin zan ifade etmesi kaçınılmazdır. Ancak bu zan gelişigüzel bir zan olmanın ötesinde zannın en üst derecesidir. Bu nedenle kiyasın bilgi değeri rey-i galib, zann-1 ekber, zann-1 galib vb. şekillerde nitelendirilmiştir.

Kıyas yoluyla elde edilen bu bilginin mükellefiyet oluşturmadaki rolünü cevaplandırmada ilim ile amel arasında bir ayırımın yapılması ve dinin esasları kabul edilen zaruriyatta kat'î bilginin zorunlu, içtihada açık

121 Şafiî, Risale, 477, 483, 497.

$$
\text { cumhuriget ilahigat dergisi 2o, sy. 1 (Haziran 2016): 61-88. }
$$


olan konularda ise zannî bilginin yeterli görülmüş olması, furû fıkıh aç1sından kaçınılmazdır. Zira nassların hayatla olan bağlantısı ancak bu yolla sağlanır. Bu nedenle olsa gerek, usûlcüler ihtimali içermesine rağmen k1yasla ulaşılan zannî bilgiyle amelin vacipliğini özellikle vurgulamışlardır. Bu konuda naklî delillerin yanı sıra sahabenin içtihatla hüküm verme hususunda icma etmiş olmalarının; tahkīku'l-menâtın, haber-i vahidin, müevvel lafzın ve tahsise uğramış umûmî lafzın ihtimali barındırmalarına rağmen amel için yeterli kabul edilmesinin de önemli bir gerekçe olduğu kanaatindeyiz.

\section{KAYNAKÇA}

Ali Haydar. Dürerï'l-Hükkâm Şerhu Mecelleti'l-Ahkâm, ta'rib. Fehmi el-Hüseynî, Beyrut: Dâru'l-Cîl, 1991.

Âmidî, Seyfüddin. el-ïhkâm fî Usûli'l-Ahkâm. yy. 1968.

Apaydın, H. Yunus. "Kıyas", Türkiye Diyanet Vakfi İslam Ansiklopedisi, 25: 529-539. Ankara: TDV Yayınları, 2002.

Apaydın, H. Yunus. "Zan”, Türkiye Diyanet Vakfi İslam Ansiklopedisi, 44: 122-124. Ankara: TDV Yayınları, 2013

Apaydın, H. Yunus. "İçtihad”, Türkiye Diyanet Vakfi İslam Ansiklopedisi, 21: 432-445. Ankara: TDV Yayınları, 2000.

Bacî, Ebü'l-Velid. İhkamu'l-Fusûl fi Ahkami'l-Usûl, thk. Abdü'l-Mecid Türkî, Beyrut: Dârü'l-Ğarbı'l-İslâmî, 1995.

Bâkıllânî, Ebû Bekr Muhammed. et-Takrib ve'l-İrş̧ad: es-Sagîr, thk. Abdülhamid b. Ali Ebû Zenid, Beyrut: Müessesetü'r-Risâle, 1993.

Bardakoğlu, Ali. "Delil", Türkiye Diyanet Vakfi İslam Ansiklopedisi, 9: 138-140. Ankara: TDV Yayınları, 1994.

Basrî, Ebü'l-Hüseyn. el-Mu'temed fî Usûli'l-F $r k h$, thk. Muhammed Hamidullah. Dımaşk: el-Ma'hadü'l-İlmî el-Fransî li'd-Diraseti'l-Arabiyye, 1964.

Bedir, Murtaza. Sünnet, Hz. Peygamber'in Evrensel Mesaji. İstanbul: İsam yay. 2006.

Buhârî, Abdülaziz. Keşsfü'l-Esrar ala Usûli'l-Pezdevî. Beyrut: Daru'l-Kütübi'l-İlmiyye, 1994.

Cabirî, Muhammed Abid. Arap-İslam Kültürünün Akll Yapısı: Arap-İslam Kültüründeki Bilgi Sistemlerinin Eleștirel Bir Analizi, çev. Burhan Köroğlu, Hasan Hacak, Ekrem Demirli, İstanbul: Kitabevi, 1999.

Cessâs, Ebû Bekr. el-Fusûl fi'l-Usûl, thk. Acil Casim en-Neşmi, Kuveyt: Vüzaratü'l-Evkafi ve'ş-Şuû́'ni' '-İslamiyyeti, 1994.

Cuma, İdris. er-Re'y ve Eserühü fi'l- Fıkhi'l-İslâmî. Kahire: Matbaatü İsa el-Babî el-Halebî, 2006.

Cüveynî, İ̀mamü'l-Harameyn. el-Burhan fí Usûli'l-F $k$ kh, thk. Abdülazim ed-Dib, Devha: Câmiatu Katar, 1978.

Cürcanî, Seyyid Şerif. Şerhu'l-Mevakuf, Hasan Çelebî ve Siyalkutî haşiyesi ile birlikte. Kum: İntişarat-1 Şerif er-Radi, 1907.

$$
\text { cumhuriget theology journal 20, no. 1 (June 2016): 61-88. }
$$


Cürcanî, Seyyid Şerif. et-Tarifât. Mısır: Şirketü ve Matbaatü Mustafa el-Babî el-Halebî, 1938.

Çaldak, Hüseyin. Kıyas'ın Mantıkta ve İslami ilimlerde Kullanım Biçimi, Cumhuriyet Üniversitesi İlahiyat Fakültesi Dergisi, 11: sy. 1 (2007): 235-262.

Debûsî, Ebû Zeyd Ubeydullah. Takvîmu'l-Edille fi Usûli'l-Fıkh, thk. Halil Muhyiddin elMeys. Beyrut: Daru'1-Kütübi'l-İlmiyye, 2001.

Demir, Osman. "Yakin”, Türkiye Diyanet Yayınları, 43: 271-273. Ankara: TDV Yayınları, 2013.

Duman, Soner. "Şafiî̀'nin Hukuk Metodolojisinde Kıyas Kavramının Anlam ve Kapsamı", Ekev Akademi Dergisi 14, sy. 42 (Kış 2010): 149-162

Duman, Soner. "er-Redd Ale'l-Mantıkıyyîn Adlı Eseri Çerçevesinde İbn Teymiyye'nin Fıkhî Kıyas ile Mantıkî Kıyas Arasındaki İlişkiye Dair Görüşleri”, Hikmet Yurdu, 3, sy. 6 (Temmuz-Aralık 2010): 193-210.

Esad es-Saîdî, Abdulmelik Abdurrahman. "Mizanü'l-Usûl fi Netâicu'l-Ukûl Dirase, Tahkik ve Ta 'lik” Doktora Tezi, Ümmü'l-Kurra Üniversitesi, Mekke, 1984.

Ebû Ya'la, Muhammed el-Ferra. el-Udde fí Usuli'l-Fıkh, thk. Ahmed b. Ali Seyr Mübarekî. Riyad: 1990.

Ebû Zehra, Muhammed. Usûlü'l-Fıkh. Kahire: Daru'l-Fikri'l-Arabî, ts.

Ebû Zehra, Muhammed. İmam Şafî̀. trc. Osman Kesikoğlu, Ankara: Diyanet İşleri Başkanlı $\breve{g}_{1}, 1969$.

Gazzâlî, Ebû Hamid Muhammed. el-Mustasfâ min İlmi'l-Usûl, thk. Hamza b. Züheyr Hafız. Beyrut: Müessetü'r-Risale, 1997.

Gazzâlî, Ebû Hamid Muhammed. Şifầ $\hat{u}^{\prime} l$-Ğalîl. Beyrut: 1999.

Halife Ba Bekr, el-Hüseyn. el-İctihad bi'r-rey fi Medreseti'l-Hicâzi'l-Fıkhiyye. Kahire: Mektebetü'z-Zehra, 1998.

Hamd b. Hamdi, Saîdi. Muvazene beyne Delaleti'n-Nas ve'l-Kıyasi'l-Usûl ve Eseru zalike ale'l-Furû'i'l-Fıkhiyye. Kahire: Dârü'l-Harir li't-Tıbaa, 1993.

Hamevî, Ahmed b. Muhammed. Gamzu Uyûni'l-Basâir: Şerhu Kitâbi'l-Eşbâh ve'nNezâir. Beyrut: Dârü'l-Kütübi'l-İlmiyye, 1985.

Hasan, Ahmed. İslam Hukukunun Doğuşu ve Gelişimi, trc. Ali Hakan Çavuşoğlu-Hüseyin Esen. İstanbul: İz Yayıncılık, 1999.

İbn Abdüşşsekür. Müsellemüs'Subût, Fevatihu'r-Rahamût ile beraber, zabt. Abdullah Mahmud Muhammed Ömer. Beyrut: Daru'l-Kütübi'l-İlmiyye, 2002.

İbn Berhân, Ebü'l-Feth. el-Vüsûl ile'l-Usûl, thk. Abdülhamîd Ali Ebû Züneyd. Riyad: Mektebtü'l-Mearif, 1984.

İbn Hacib, Cemalüddin. Muhtasaru Münteha's-Sûl ve'l-Emel fỉ İlmiyyi'l-Usûl ve'l-Cedel, thk. Nezir Hamadu. Beyrut: Daru İbn Hazm, 2006.

İbn Hacib, Cemalüddin. Muhtasar'i-bni'l-Hacib, Ref'u'l-Hacib ile birlikte, thk. Ali Muhammed Muavviz, Adil Ahmed Abdülmevcud. Beyrut: Âlemü'l-Kütüb, 1999.

İbn Hazm, Ebu Muhammed. el-İhkâm fî Usûli'l-Ahkam, thk. Ahmed Muhammed Şakir. Beyrut: el-Afakï'l-Cedide, 1983.

İbn Hümam, Kemalüddin. Kitabü't-Tahrir, Teysir'u-Tahrir ile birlikte. Mısır: Matbaatü Mustafa el-Babî el-Halebî, 1351.

İbn Kudâme, Muvafikuddin. Ravzatü'n-Nâzır ve Cünnetü'l-Munâzir. Nüzhetü'l-Hatır ile birlikte Riyad: Mektebetü'l-Meârif, 1984.

İbn Manzur, Cemalüddin. Lisanü'l-Arab. Beyrut: 2000.

İbn Nüceym, Zeynü'l-Abidin. el-Eşbah ve'n-Nezâir. Gamzu Uyûnî'l-Besâir ile birlikte. Beyrut: Dârü'l-Kütübi'l-İlmiyye, Beyrut 1985.

$$
\text { cumhuriget ilahigat dergisi 20, sy. 1 (Haziran 2016): 61-88. }
$$


İbn Rüşd, Ebü'l-Velîd. ez-Zarurî fí Usûli'l-Fıkh ev Muhtasaru'l-Mustasfa, thk. Cemalüddin el-Ulvî. Beyrut: Daru'l-Ğarbi'l-İslamî, 1994.

İsnevî, Cemalüddin. Nihayetü's-Sû'l fî Şerhi Minhaci'l-Vusûl. Süllemü'l-Vusul ile birlikte. Kahire: Âlemü'l-Kütüb, 1343.

Kacır, Temel. "Hanefi Usulcülerinden Kadı Ebû Zeyd Debûsî’nin Kıyas Nazariyesi (Takvimü'l-Edille Adlı Eseri Çerçevesinde)" Yüksek lisans tezi, Gazi Üniversitesi, Ankara 2007.

Karadaş, Cağfer. "Yakin ve İtikad”, Uludă̆ Üniversitesi İlahiyat Fakültesi Dergisi, 10, sy, 1 (2001): 113-126.

Koşum, Adnan. İslam Hukuk Tarihinde Kıyasın Oluşum ve Gelişim Süreci (Başlangıcından Mezheplerin Teşekkülüne Kadar). İzmir: Işık Akademi Yayınları, 2010.

Kurtubî, Ebu Abdillah Muhammed.el-Camiu' li Ahkâmi'l-Kur'an. Riyad: Daru Alemi'lKütüb, 2003.

Lâmiş̂î, Ebü's-Sena Mahmûd. Kitâb fî Usûli'l-Fıkh, thk. Abdülmecid Türkî. Beyrut: Dârü'l-Garbi'l-İ̀slâmî, 1995.

Leknevî, Abdülalî Muhammed. Fevatihü'r-Rahamût bi Şerhi Müsellemi's-Sübût, zabt ve tash. Abdullah Mahmûd Muhammed Ömer. Beyrut: Dârü'l-Kütübi'l-İlmiyye, 2002.

Makarrî, Ahmed. el-Kavaîd. thk. Ahmed b. Abdullah. Mekke: Merkezü İhyai't-Türasi'lİslamî, ts.

Mennun, İsa. Nibrasü'l-Ukûl fî Tahkiki'l-Klyas inde Ulemâi'l-Usûl. Matbaatü'z-Tezamüni'l-Ehva. Kahire: Matbaatü'z-Tezamüni'l-Ehva, 1345.

Nemle, Abdülkerim. el-Mühezzeb fî İlmi Usûli'l-Fıkhi'l-Mukaren: Tahrir li-Mesailihi ve Dirasetiha Dirase Nazariyye Tatbikiyye. Riyad: Mektebetü'r-Rüşd, 1999.

Nesefî, Ebu'l-Berekat. Keşfu'l-Esrar, Nuru'l-Envar ve Kamerü'l-Akmar'la birlikte. İstanbul: İhsan Kitabevi, 1986.

Nevevî, Ebû Zekeriyya Muhyiddin. el-Mecmu' Şerhu'l-Mühezzeb, thk. Muhammed Bahît el'Mutî. Cidde: Mektebetü'l-İrşad, ts.

Pezdevî, Ebü'l-Usr. Usûli'l-Pezdevî, Keşfü'l-Esrar ile birlikte. Beyrut: Daru'l-Kütübi'lİlmiyye, 1994.

Razî, Fahreddin. el-Mahsul fi İlmi'l-Usûl, thk. Taha Cabir Feyyaz el-Alvanî. Beyrut: Müessesetü'r-Risale, 1997.

Sadrüşşerîa, Ubeydullāh b. Mes'ûd. et-Tavzîh, Şerhü't-Telvih ale't-Tavzih ile birlikte, Beyrut: Dârü'l-Kütübi'l-İlmiyye, 1957.

Salih, Muhammed Edip. Tefsirü'n-Nusûs fi'l-Fıkhi'l-İslâmî. Beyrut: el-Mektebetü'l-İslamiyye, 1993.

Schacht, Joseph. İslam Hukukuna Giriş, trc. Mehmet Dağ-Abdülkadir Şener. Ankara: Ankara Üniversitesi Basım Evi, 1997.

Serahsî, Ebu Bekr. Usulü's-Serahsî, thk. Ebu'l-Vefa el-Efğanî, Beyrut: Daru'l-Kütübi'lİlmiyye, 1993.

Sem ânî, Ebû'l-Muzaffer Mansur. Kavâdıu'l-Edille fi'l-Usûl, thk. Muhammed Hasan İsmail eş-Şafîi, Beyrut: Daru'l-Kütübi'l-İlmiyye, 1997.

Seyıd Bey. Medhal. İstanbul: Matbaa Amiriyye, 1333.

Sübkî, Taceddin. Ref'u'l-Hacib an Muhtasar'i-bni'l-Hacib, thk. Ali Muhammed Muavviz, Adil Ahmed Abdülmevcud. Beyrut: Âlemü'l-Kütüb, 1999.

Şaban, Zekiyyüddin. Usûlu'l-Fıkhı'l-İslâmî. yy: ts.

Şafî̂, Muhammed İdris. er-Risale, thk. Ahmed Muhammed Şakir. Beyrut: Darü'l-Kütübi'l-İlmiyye, ts.

$$
\text { cumhuriget theology journal 20, no. 1 (June 2016): 61-88. }
$$




\section{8 | Temel KACIR}

Şatıbî, Ebû İshak. el-Muvafakât fî Usûli'ş-Şerîa, şerh, Abdullah Dıraz. Beyrut: Dârü'l-Kütübi'l-İlmiyye, 1991.

Şelebî, Mustafa. Usûlü'l-Fikhi'l-íslamî. Beyrut: ed-Darü'l-Cami'iyye, ts.

Şeşerî, Sa'd b. Nasır. el-Kat' ve'z-Zan inde'l-Usûliyyin: Hakikatuhuma ve Turuku İstifadetihima ve Ahkamuha. Riyad: Darü'l-Hubeyb, 1997

Şevkanî, Ebu Abdullah Muhammed. İrşadü'l-Fuhûl ila Tahkîki'l-Hak min İlmi'l-Usûl, thk. Ebu Hafs Sami b. el-Arabî. Riyad: Daru'l-Fazile, 2000.

Şirâzî, Ebû İshak Cemaleddin. Şerhu'l-Lüma', thk. Abdülmecid Türkî. Beyrut: Dârü'l-Garbi'l-İslâmî, 1988.

Teftazanî, Sa'deddin Mesud b. Ömer. Şerhü't-Telvih ale't-Tavzîh. Beyrut: Dârü'l-Kütübi'lİlmiyye, 1957.

Tahânevî, Muhammed b. A'la. Mevsuâtu Keşşâfi Istılahati'l-Fünûn ve'l-Ulûm, thk. Ali Dahruc; çev. Corc Zeynatî, Abdullah Halidî. Beyrut: Mektebetu Lübnan, 1996.

Zerkâ, Ahmed. Şerhü'l-Kavâ'idi'l-Fıkhiyye. Beyrut: Dârü'l-Garbi'l-İslâmî, 1983.

Zerkeşî, Bedrüddin. el-Bahrï'l-Muhît fi Usûli'l-Fıkh. Ğardek: Daru's-Safve, 1992.

Züheyr, Muhammed Ebu'n-Nur. Usûlü'l-Fıkh. Kahire: el-Mektebetü’l-Ezheriyyetü li’tTüras, 2004. 